\title{
The European ME/CFS Biomarker Landscape project: an initiative of the European network EUROMENE
}

\author{
Carmen Scheibenbogen ${ }^{1^{*}}$ (D), Helma Freitag ${ }^{1}$, Julià Blanco ${ }^{3,4}$, Enrica Capelli, ${ }^{5,6}$, Eliana Lacerda ${ }^{7}$, Jerome Authier ${ }^{8}$, \\ Mira Meeus 9,10,11, Jesus Castro Marrero ${ }^{12}$, Zaiga Nora-Krukle², Elisa Oltra ${ }^{13,14}$, Elin Bolle Strand ${ }^{15,16}$, \\ Evelina Shikova ${ }^{17}$, Slobodan Sekulic ${ }^{18}$ and Modra Murovska ${ }^{2}$
}

\begin{abstract}
Myalgic encephalomyelitis or chronic fatigue syndrome (ME/CFS) is a common and severe disease with a considerable social and economic impact. So far, the etiology is not known, and neither a diagnostic marker nor licensed treatments are available yet. The EUROMENE network of European researchers and clinicians aims to promote cooperation and advance research on ME/CFS. To improve diagnosis and facilitate the analysis of clinical trials surrogate markers are urgently needed. As a first step for developing such biomarkers for clinical use a database of active biomarker research in Europe was established called the ME/CFS EUROMENE Biomarker Landscape project and the results are presented in this review. Further we suggest strategies to improve biomarker development and encourage researchers to take these into consideration for designing and reporting biomarker studies.
\end{abstract}

Keywords: Biomarker, ME/CFS, European network, Landscape project, Diagnostic, Autoantibodies, Autoimmunity, B cell, Cytokines, Viral

\section{Biomarker in ME/CFS}

Although the exact pathogenesis of myalgic encephalomyelitis or chronic fatigue syndrome (ME/CFS) is still unknown, the most plausible hypothesis is that it is a complex multifactorial syndrome in which immunological and environmental factors play a crucial role. In addition, the severe fatigue, post-exertional malaise, cognitive impairment, and autonomic dysfunction that delineate the disease point to the involvement of both the nervous system as well as metabolic disturbances [1]. Infection by various pathogens, including herpes viruses and enteroviruses, but also intracellular bacteria, are known as triggers of disease. The complex clinical picture and the disagreement on potential pathomechanisms make ME/CFS a controversial entity and compel the research

\footnotetext{
*Correspondence: carmen.Scheibenbogen@charite.de

${ }^{1}$ Institute for Medical Immunology, Charité-Universitätsmedizin Berlin, Campus Virchow, Augustenburger Platz 1/Sudstrasse 2, 13353 Berlin, Germany

Full list of author information is available at the end of the article
}

for disease biomarkers that could aid in the diagnostic and clinical management. Biomarker per definition may include both markers with a certain sensitivity and specificity for diagnosing ME/CFS as well as those which may allow to classify subtypes of the disease, be of value as indicators of prognosis, and to be predictive for response to treatment [2].

\section{The EUROMENE ME/CFS Biomarker Landscape project}

EUROMENE is a network of researchers and clinicians from 17 European countries and one COST (Cooperation in Science and Technology) near neighbor country on ME/CFS supported by the European COST program within Horizon 2020 (http://www.cost.eu/ COST_Actions/ca/CA15111).

The aims of EUROMENE are to foster strategies for collaboration and harmonization of diagnosis and research, and to compile an inventory of clinical and scientific data in ME/CFS. The Biomarker working group will also try to 


\section{CFS/ME biomarker research in Europe}
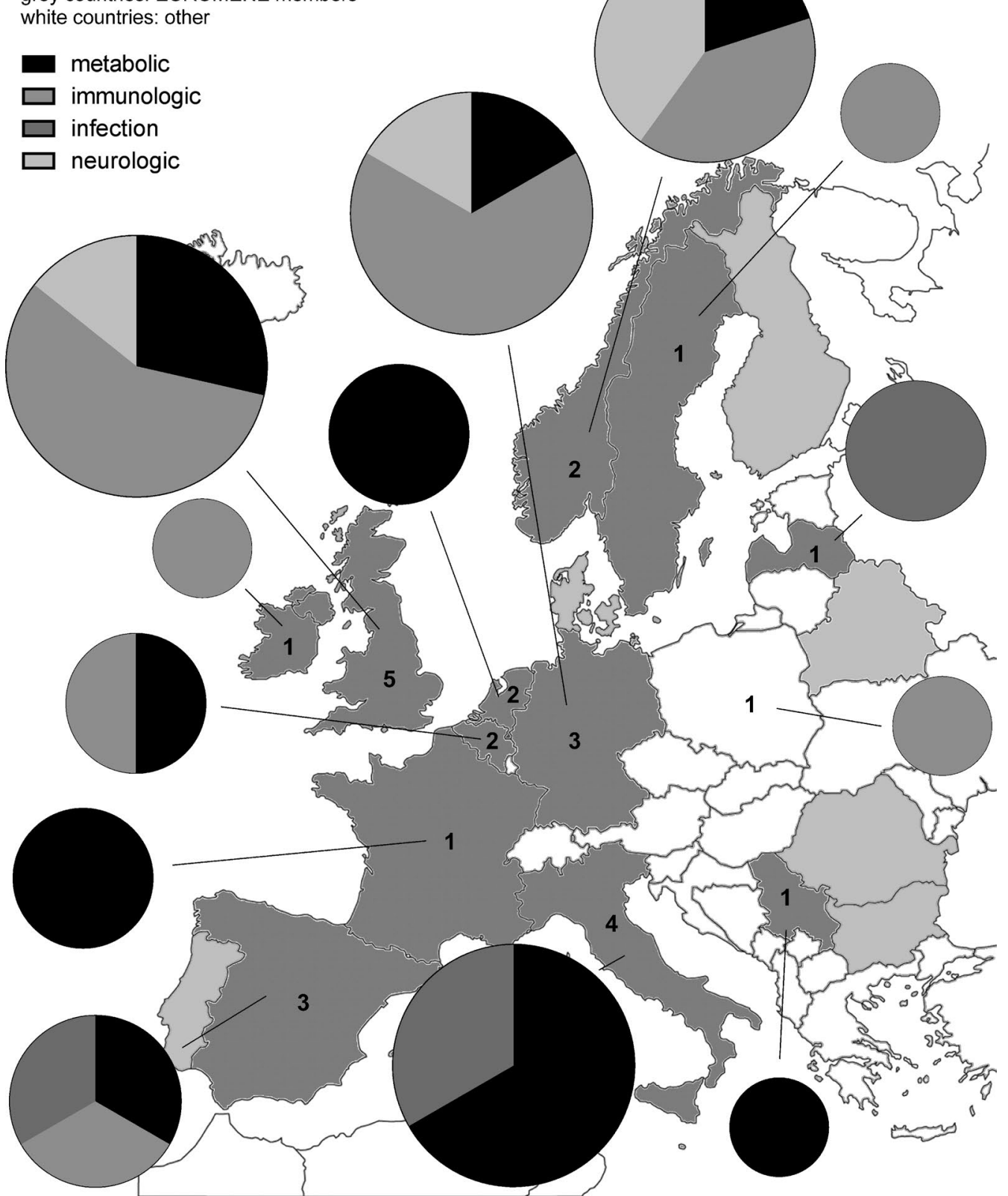

Fig. 1 Biomarker studies were categorized as metabolic, immunological, neurological or infection-associated. The data was visualized as total numbers of studies (size of cake) per category (piece of cake) from each country, and the numbers of active biomarker research groups is indicated in the countries. EUROMENE countries are indicated by grey (dark grey countries with published studies, light grey those without studies) and nonEUROMENE by white

develop guidelines for the usage of biomarkers and synchronization of biomarker research.

As a first step, a database for active biomarker research in Europe was established called the EUROMENE ME/CFS Biomarker Landscape project. To achieve this, EUROMENE members performed a search for publications on biomarkers within their countries. The search strategy used the medical subject headings (MeSH) term "chronic fatigue syndrome", which includes myalgic encephalomyelitis, and the respective country, and selected all publications from the last 5 years (20122016). The searches were reviewed by members of the 
biomarker working group. Studies not involving patients with ME/CFS, non-biomarker, and sole treatment studies were excluded, only one review article was included.

A total number of 39 studies were identified. Studies were categorized as being immunological, infectionrelated, metabolic or neurological. We summarize the findings in Fig. 1, which shows the number and type of studies identified in each country, represented by pie charts-their sizes being proportional to the number of identified studies, and their pieces representing the distinct categories of the studies. The number of research groups working on ME/CFS biomarkers in the EU countries is also illustrated in Fig. 1. Countries from which no publications on ME/CFS biomarker could be retrieved are shown in light green/grey, and European countries not participating in the EUROMENE are shown in white. The references listed per countries are shown in Table 1.

Studies on immune markers $(n=15)$ in ME/CFS explored immunoglobulins, autoantibodies, cytokines, and immune cell phenotype and function (summarized in Table 2) [3-17]. Four of 5 of the studies on ME/CFSassociated infection markers were focused on XMRV and confirmed the absence of this virus in European ME/CFS cohorts [18-22]. Neurological biomarker studies $(n=4)$

Table 1 ME/CFS biomarker studies in Europe 2012-2016

\begin{tabular}{lll}
\hline Country & Category & Study references \\
\hline Belgium & Metabolic & {$[27]$} \\
& Immunologic & {$[3]$} \\
France & Metabolic & {$[28,29]$} \\
Germany & Metabolic & {$[30]$} \\
& Immunologic & {$[4-7]$} \\
Ireland & Neurologic & {$[23]$} \\
Italy & Immunologic & {$[8]$} \\
& Metabolic & {$[31-34]$} \\
Latvia & Infection & {$[18,19]$} \\
Netherlands & Infection & {$[20,21]$} \\
Norway & Metabolic & {$[35,36]$} \\
& Metabolic & {$[37]$} \\
& Immunologic & {$[9,10]$} \\
Poland* & Neurologic & {$[24,25]$} \\
Serbia & Immunologic & {$[11]$} \\
Spain & Metabolic & {$[38]$} \\
& Metabolic & {$[39]$} \\
Sweden & Immunologic & {$[12]$} \\
UK & Infection & {$[22]$} \\
& Immunologic & {$[13]$} \\
& Metabolic & {$[40,41]$} \\
\hline Non-EvROMENE & {$[14-17]$} \\
& Neurologic & {$[26]$} \\
\hline
\end{tabular}

* Non-EUROMENE country focused on neurotransmitter regulation, but excluded imaging and functional studies [23-26]. The papers which could be retrieved for potential metabolic markers $(n=15)$ studied mitochondrial dysfunction, oxidative stress, cortisol regulation, and more comprehensive metabolic pathways [27-41].

\section{Discussion}

So far there is no single biomarker available for diagnostic use in ME/CFS. Most studies identified here were exploratory in design and lack sex and age-matched control groups or validation cohorts thus having a low evidence level as summarized for the immune marker studies in Table 2 [42]. Some studies report inconsistent data, too. For example an expansion of transitional and naïve B cells and reduced plasmablast levels was reported in one study [14], but could not be confirmed in two other studies [4, 12]. Immune cell phenotype and function analyses are, of course, hampered by variations in sampling and methodological differences between laboratories as most flow cytometric assays are not standardized. Further, immunological biomarkers reported mostly show alterations in subgroups only or with wide overlap to healthy control groups. Such heterogeneous results may be related to the fact that subgroups of ME/CFS patients exist with different immunological pathomechanisms. This concept is supported by the existence of clinical subgroups with heterogeneity in disease onset (infection- versus non-infection triggered), the variability of immune-associated symptoms, and the divergent response to $\mathrm{B}$ cell depletion therapy [43]. Research activity in infection markers on ME/ CFS across Europe is sparse; however, there is currently no evidence from the available literature that there is a specific serological signature aiding in diagnosis of ME/CFS.

Similar to immunological markers, there is no single neurological or metabolic marker with sufficient specificity and sensitivity as a tool in ME/CFS diagnosis yet. However, recent studies analyzing multiple metabolites could show specific alterations in the majority of ME/CFS patients [37, 44-46] pointing to a probably common and specific metabolic profile. Further, metabolic studies consistently revealed different gender-related patterns [37, $44,46]$. Thus, instead of searching single markers fitting for diagnosing all patients, multiplexed determinations of biomarkers analyzing pathways together with patient stratification, may be necessary to develop diagnostic assays with sufficient sensitivity and specificity [47].

\section{Conclusions}

Heterogeneity of biomarker studies with different case definitions, low number of patients, lack of matched control groups, missing validation studies and potentially subgroup heterogeneity are possible reasons why no 
Table 2 Immune marker studies

\begin{tabular}{|c|c|c|c|c|c|c|}
\hline Marker(Ref) & Design of study & $\begin{array}{l}\text { ME/CFS pat. } n \text { / } \\
\text { diagnostic criteria }\end{array}$ & $\begin{array}{l}\text { Controls n/age- } \\
\text { and sex-matched }\end{array}$ & $\begin{array}{l}\text { Sub group } \\
\text { analysis }\end{array}$ & $\begin{array}{l}\text { Validation } \\
\text { cohort }\end{array}$ & $\begin{array}{l}\text { Results in ME/ } \\
\text { CFS compared } \\
\text { to healthy controls }\end{array}$ \\
\hline $\begin{array}{l}\text { Immunoglobulins (lg), } \\
\text { MBL [4] }\end{array}$ & Confirmatory & $300 / C C C$ & Reference range & Yes & 168 & $\begin{array}{l}\text { 25\% diminished lg } \\
25 \% \text { elevated lg } \\
15 \% \text { MBL diminished }\end{array}$ \\
\hline B cells [4] & & $65 /$ CCC & 20/no & & 20 & $\begin{array}{l}\text { B cell subsets not } \\
\text { altered }\end{array}$ \\
\hline lgG3 lgE COMT [5] & Exploratory & 76/CCC & $74 /$ no & Yes & No & $\begin{array}{l}\text { COMT rs } 4680 \text { is asso- } \\
\text { ciated with lgG3 } \\
\text { and lgE levels }\end{array}$ \\
\hline $\begin{array}{l}\text { EBV-specific lgG } \\
\text { EBV-B and T cells [7] }\end{array}$ & $\begin{array}{l}\text { Confirmatory } \\
\text { Exploratory }\end{array}$ & $\begin{array}{l}63 / \mathrm{CDC} \\
17\end{array}$ & $\begin{array}{l}57 / \text { no } \\
12 / \text { no }\end{array}$ & Yes & $\begin{array}{l}387 \\
\text { No }\end{array}$ & $\begin{array}{l}\text { More EBNA-IgG neg. } \\
\text { More VCA-IgM pos } \\
\text { EBV B-/T cells lower }\end{array}$ \\
\hline $\begin{array}{l}\text { HSP60 auto-antibodies } \\
\text { [13] }\end{array}$ & Exploratory & $69 /$ CCC & $76 /$ no & Yes & 61 & $\begin{array}{l}\text { Few lgG epitopes spe- } \\
\text { cific for ME/CFS }\end{array}$ \\
\hline $\begin{array}{l}\text { Neurotransmitter- } \\
\text { receptor auto-anti- } \\
\text { bodies [6] }\end{array}$ & $\begin{array}{l}\text { Exploratory/con- } \\
\text { firmatory }\end{array}$ & $268 / C C C$ & 108/yes & Yes & No & $\begin{array}{l}\text { Elevated } \beta 2 \\
\text { adrenergic, M3/4 } \\
\text { cholinergic receptor } \\
\text { antibodies in a } \\
\text { subset of ME/CFS }\end{array}$ \\
\hline Cytokines [10] & Exploratory & $120 / C D C$ & 68/yes & Yes & No & $\begin{array}{l}\text { Multiple cytokines no } \\
\text { differences }\end{array}$ \\
\hline Cytokines [8] & Exploratory & $48 / C D C$ & $35 /$ no & No & No & $\begin{array}{l}\text { Elevated CRP, TNF- } \\
\text { alpha and IL-6 levels }\end{array}$ \\
\hline Cytokines [15] & Review & 38 papers & & & & $\begin{array}{l}\text { TGF- } \beta \text { levels elevated } \\
\text { in } 5 \text { of } 8 \text { studies } \\
(63 \%)\end{array}$ \\
\hline Cytokines [3] & Exploratory & $16 / C D C$ & 14/yes & No & No & $\begin{array}{l}\text { Increase of IL-1b, IL-8, } \\
\text { |L-10 and TNF-alpha } \\
\text { levels }\end{array}$ \\
\hline BAFF, APRIL [9] & Exploratory & $70 / C C C \&$ CDC & $56 /$ no & Yes & No & $\begin{array}{l}\text { Elevated BAFF } \\
\text { baseline } \\
\text { APRIL not altered }\end{array}$ \\
\hline T cells $[11]$ & Exploratory & 139/CDC & $40 /$ no & Yes & No & $\begin{array}{l}\text { Increased CD38 } \\
\text { expression on CD8 }{ }^{+} \\
\text {T cells }\end{array}$ \\
\hline NK, T and B cells [12] & Exploratory & 22/CDC & $30 /$ no & No & No & $\begin{array}{l}\text { Treg higher, Tem } \\
\text { lower, NK cell CD69, } \\
\text { NKp46 higher, CD25 } \\
\text { lower, B cell subsets } \\
\text { not altered }\end{array}$ \\
\hline B cells [16] & Exploratory & $38 / C C C \&$ CDC & $32 /$ yes & No & No & $\begin{array}{l}\text { Increased CD24 } \\
\text { expression on total } \\
\text { B cells } \\
\text { Elevated number of } \\
\text { CD21+ CD38- B } \\
\text { cells }\end{array}$ \\
\hline B cells [14] & Exploratory & $33 / C C C \&$ CDC & 24/yes & No & No & $\begin{array}{l}\text { Increased number of } \\
\text { naïve and transi- } \\
\text { tional B cells }\end{array}$ \\
\hline $\begin{array}{l}\text { miRNA in immune cell } \\
\text { subsets [17] }\end{array}$ & Exploratory & $35 / C C C \&$ CDC & $50 /$ no & No & No & $\begin{array}{l}34 \text { miRNAs upregu- } \\
\text { lated in NK, B cells } \\
\text { and monocytes }\end{array}$ \\
\hline
\end{tabular}

Diagnostic criteria: CDC the Centers of Disease Control or Fukuda Criteria [49], CCC Canadian Consensus Criteria

diagnostic biomarkers are available yet. Further, as result of the low amount of funding in CFS/ME research few and often small studies were performed so far. Therefore, strategies to improve the quality and to facilitate the comparability of biomarker studies are needed (summarized in Table 3). This starts with well-defined patient cohorts 
Table 3 Strategies for development of diagnostic biomarkers in ME/CFS

1. Standardization of sample collection and assay procedures

2. Use of an uniform clinical case definition

3. Use of questionnaires to assess symptoms and severity to define subgroups

4. Stratification of patients according to sex, disease onset, and disease duration

5. Include sex- and age-matched control groups

6. Sufficient sample size and predefined hypotheses (statistical power)

7. Confirmation of results in validation and multi-center cohort studies

8. Study combinations of biomarkers, perform pathway analysis or functional studies

using strict case definitions [47], standardized and quantitative symptom assessment for subgroup analyses, well-defined age- and sex-matched controls, and large enough cohort size and a predefined hypothesis to power the statistical analysis. Detailed description of cohorts, assays performed and results achieved are important to facilitate confirmation studies. Reproducing results in cohorts from different countries, developing Standard Operating Procedures (SOPs) for assays, and multicenter studies are important steps for evaluating the suitability of biomarkers of interest as diagnostic markers. The building of translational networks of clinical and basic research groups like promoted in EUROMENE is an important first step to achieve such goals. Finally, to promote research it is crucial to increase funding for ME/ CFS which is currently still far below the budget funds for most other serious diseases in both the EU and the US funding agencies, such as the National Institutes of Health (NIH) [48].

\begin{abstract}
Abbreviations
AB: antibody; APRIL: a proliferation-inducing ligand; BAFF: B-lymphocyte activating factor; CCC: Canadian Consensus Criteria; CD: cluster of differentiation; CDC: Fukuda Criteria (Centers for Disease Control and Prevention); CFS: chronic fatigue syndrome; COMT: catechol-O-methyltransferase; COST: Cooperation in Science and Technology; CRP: C-reactive protein; EBNA: EBV nuclear antigen; EBV: Epstein-Barr virus; EU: European Union; EUROMENE: European Network on Myalgic Encephalomyelitis/Chronic Fatique Syndrome; HSP: heat shock protein; Ig: immune globuline; IL: interleukine; MBL: mannose binding lectin; ME: myalgic encephalomyelitis; MeSH: medical subject headings; $\mathrm{NIH}$ : National Institutes of Health; NK: natural killer cells; RNA: ribonucleic acid; SOP: standard operating procedure; TGF: transforming growth factor; TNF: tumor necrosis factor; US: United States of America; VCA: viral capside antigen; XMRV: xenotropic murine leukemia virus-related virus.
\end{abstract}

\section{Authors' contributions}

CS designed the study and research guidelines, reviewed data received from the different partner countries. CS and JB were major contributors in writing the manuscript. HF reviewed and analyzed the data, did research for the nonEUROMENE countries and prepared figures and tables. All other authors collected and reviewed data for their own country. MM is head of the EUROMENE cooperation group within COST network. All authors read and approved the final manuscript.

\begin{abstract}
Author details
${ }^{1}$ Institute for Medical Immunology, Charité-Universitätsmedizin Berlin,

Campus Virchow, Augustenburger Platz 1/Sudstrasse 2, 13353 Berlin,

Germany. ${ }^{2}$ August Kirchenstein Institute of Microbiology and Virology, Riga

Stradins University, Dzirciema iela 16, Kurzemes rajons, Rīga 1007, Latvia.

${ }^{3}$ Institut de Recerca de la Sida IrsiCaixa-HIVACAT, Institut d'Investigació en Ciències de la Salut Germans Trias i Pujol, IGTP, UAB, Carretera del Canyet, s/n, 08916 Badalona, Spain. ${ }^{4}$ Universitat de Vic-UCC, Carrer de la Sagrada Família, 7, 08500 Vic Barcelona, Spain. ${ }^{5}$ Deptartment of Earth and Environmental Sciences, University of Pavia, Via Ferrata 7, 27100 Pavia, Italy. ${ }^{6}$ Centre for Health Technologies (CHT), University of Pavia, Via Ferrata 5, 27100 Pavia, Italy. ${ }^{7}$ Clinical Research Department, Faculty of Infectious \& Tropical Diseases, London School of Hygiene \& Tropical Medicine, Keppel St, Bloomsbury, London WC1E 7HT, UK. ${ }^{8}$ Faculty of Medicine, Paris Est-Creteil University, 8 rue du General Sarrail, 94000 Creteil, France. ${ }^{9}$ Pain in Motion International Research Group, Brussels, Belgium. ${ }^{10}$ Department of Rehabilitation Sciences and Physiotherapy, Faculty of Medicine and Health Sciences, Ghent University, St. Pietersnieuwstraat 33, 9000 Ghent, Belgium. ${ }^{11}$ Department of Rehabilitation Sciences and Physiotherapy (MOVANT), Faculty of Medicine and Health Sciences, University of Antwerp, Prinsstraat 13, 2000 Antwerp, Belgium. ${ }^{12}$ Vall d'Hebron University Hospital, CFS/ME Unit, Universitat Autònoma de BarceIona, 119-129, Passeig de la Vall d'Hebron, 08035 Barcelona, Spain. ${ }^{13}$ Facultad de Medicina, Universidad Católica de Valencia, San Vicente Mártir, Carrer de Quevedo, 2, 46001 Valencia, Spain. ${ }^{14}$ Instituto Valenciano de Patología (IVP) de la Universidad Católica de Valencia San Vicente Mártir, Centro de Investigación Príncipe Felipe (CIPF), Carrer d'Eduardo Primo Yúfera, 3, 46012 Valencia, Spain. ${ }^{15}$ Division of Medicine, CFS/ME Center, Oslo University Hospital, Aker, Trondheimsveien 235, 0586 Oslo, Norway. ${ }^{16}$ Department of Paediatrics, Norwegian National Advisory Unit on CFS/ME, Rikshospitalet, Sognsvannsveien 20, 0372 Oslo, Norway. ${ }^{17}$ Department of Virology, National Center of Infectious and Parasitic Diseases, 44A General Stoletov blvd., 1233 Sofia, Bulgaria.

${ }^{18}$ Department of Neurology, Medical Faculty Novi Sad, Hajduk Veljkova 3, 21000 Novi Sad, Serbia.
\end{abstract}

\section{Acknowledgements}

This article is based upon work from COST Action CA 15111: European Network on Myalgic Encephalomyelitis/Chronic Fatigue Syndrome (EUROMENE).

\section{Competing interests}

The authors declare that they have no competing interests.

\section{Availability of data and materials}

All data generated or analyzed during this study are included in this published article.

\section{Consent for publication \\ Not applicable.}

Ethics approval and consent to participate

Not applicable.

\section{Funding}

COST Action CA 15111: European Network on Myalgic Encephalomyelitis/ Chronic Fatigue Syndrome (EUROMENE).

\section{Publisher's Note}

Springer Nature remains neutral with regard to jurisdictional claims in published maps and institutional affiliations.

Received: 29 June 2017 Accepted: 14 July 2017

Published online: 26 July 2017

\section{References}

1. Carruthers BM, van de Sande MI, De Meirleir KL, Klimas NG, Broderick G, Mitchell T, Staines D, Powles AC, Speight N, Vallings R, et al. Myalgic encephalomyelitis: international consensus criteria. J Intern Med. 2011;270:327-38. 
2. Biomarkers and surrogate endpoints. preferred definitions and conceptual framework. Clin Pharmacol Ther. 2001;69:89-95.

3. Neu D, Mairesse O, Montana X, Gilson M, Corazza F, Lefevre N, Linkowski P, Le Bon O, Verbanck P. Dimensions of pure chronic fatigue: psychophysical, cognitive and biological correlates in the chronic fatigue syndrome. Eur J Appl Physiol. 2014;114:1841-51.

4. Guenther S, Loebel M, Mooslechner AA, Knops M, Hanitsch LG, Grabowsk P, Wittke K, Meisel C, Unterwalder N, Volk HD, Scheibenbogen C. Frequent IgG subclass and mannose binding lectin deficiency in patients with chronic fatigue syndrome. Hum Immunol. 2015;76:729-35.

5. Lobel M, Mooslechner AA, Bauer S, Gunther S, Letsch A, Hanitsch LG, Grabowski P, Meisel C, Volk HD, Scheibenbogen C. Polymorphism in COMT is associated with lgG3 subclass level and susceptibility to infection in patients with chronic fatigue syndrome. J Transl Med. 2015;13:264.

6. Loebel M, Grabowski P, Heidecke H, Bauer S, Hanitsch LG, Wittke K, Meisel C, Reinke P, Volk HD, Fluge O, et al. Antibodies to beta adrenergic and muscarinic cholinergic receptors in patients with chronic fatigue syndrome. Brain Behav Immun. 2016;52:32-9.

7. Loebel M, Strohschein K, Giannini C, Koelsch U, Bauer S, Doebis C, Thomas S, Unterwalder N, von Baehr V, Reinke P, et al. Deficient EBV-specific Band T-cell response in patients with chronic fatigue syndrome. PLoS ONE. 2014;9:e85387.

8. Groeger D, O'Mahony L, Murphy EF, Bourke JF, Dinan TG, Kiely B, Shanahan F, Quigley EM. Bifidobacterium infantis 35624 modulates host inflammatory processes beyond the gut. Gut Microbes. 2013;4:325-39.

9. Lunde S, Kristoffersen EK, Sapkota D, Risa K, Dahl O, Bruland O, Mella O, Fluge O. Serum BAFF and APRIL levels, T-lymphocyte subsets, and immunoglobulins after B-cell depletion using the monoclonal anti-CD20 antibody rituximab in myalgic encephalopathy/chronic fatigue syndrome. PLOS ONE. 2016;11:e0161226.

10. Wyller VB, Sorensen O, Sulheim D, Fagermoen E, Ueland T, Mollnes TE. Plasma cytokine expression in adolescent chronic fatigue syndrome. Brain Behav Immun. 2015:46:80-6.

11. Maes M, Bosmans E, Kubera M. Increased expression of activation antigens on CD8+T lymphocytes in Myalgic Encephalomyelitis/chronic fatigue syndrome: inverse associations with lowered CD19+ expression and CD4+/CD8+ ratio, but no associations with (auto)immune, leaky gut, oxidative and nitrosative stress biomarkers. Neuro Endocrinol Lett. 2015;36:439-46.

12. Curriu M, Carrillo J, Massanella M, Rigau J, Alegre J, Puig J, Garcia-Quintana AM, Castro-Marrero J, Negredo E, Clotet B, et al. Screening NK-, B- and T-cell phenotype and function in patients suffering from chronic fatigue syndrome. J Transl Med. 2013;11:68.

13. Elfaitouri A, Herrmann B, Bolin-Wiener A, Wang Y, Gottfries CG, Zachrisson O, Pipkorn R, Ronnblom L, Blomberg J. Epitopes of microbial and human heat shock protein 60 and their recognition in myalgic encephalomyelitis. PLoS ONE. 2013;8:e81155.

14. Bradley AS, Ford B, Bansal AS. Altered functional B cell subset populations in patients with chronic fatigue syndrome compared to healthy controls. Clin Exp Immunol. 2013;172:73-80.

15. Blundell S, Ray KK, Buckland M, White PD. Chronic fatigue syndrome and circulating cytokines: a systematic review. Brain Behav Immun. 2015:50:186-95.

16. Mensah F, Bansal A, Berkovitz S, Sharma A, Reddy V, Leandro MJ, Cambridge $\mathrm{G}$. Extended $B$ cell phenotype in patients with myalgic encephalomyelitis/chronic fatigue syndrome: a cross-sectional study. Clin Exp Immunol. 2016:184:237-47.

17. Petty RD, McCarthy NE, Le Dieu R, Kerr JR. MicroRNAs hsa-miR-99b, hsamiR-330, hsa-miR-126 and hsa-miR-30c: potential diagnostic biomarkers in natural killer (NK) cells of patients with chronic fatigue syndrome (CFS)/ myalgic encephalomyelitis (ME). PLoS ONE. 2016;11:e0150904.

18. Paolucci S, Piralla A, Zanello C, Minoli L, Baldanti F. Xenotropic and polytropic murine leukemia virus-related sequences are not detected in the majority of patients with chronic fatigue syndrome. New Microbiol. 2012;35:341-4.

19. Maggi F, Bazzichi L, Sernissi F, Mazzetti P, Lanini L, Scarpellini P, Consensi A, Giacomelli C, Macera L, Vatteroni ML, et al. Absence of xenotropic murine leukemia virus-related virus in Italian patients affected by chronic fatigue syndrome, fibromyalgia, or rheumatoid arthritis. Int J Immunopathol Pharmacol. 2012;25:523-9.
20. Chapenko S, Krumina A, Logina I, Rasa S, Chistjakovs M, Sultanova A, Viksna L, Murovska M. Association of active human herpesvirus-6, -7 and parvovirus b19 infection with clinical outcomes in patients with myalgic encephalomyelitis/chronic fatigue syndrome. Adv Virol. 2012:2012:205085.

21. Rasa S, Nora-Krukle Z, Chapenko S, Krumina A, Roga S, Murovska M. No evidence of XMRV provirus sequences in patients with myalgic encephalomyelitis/chronic fatigue syndrome and individuals with unspecified encephalopathy. New Microbiol. 2014;37:17-24.

22. Oltra E, Garcia-Escudero M, Mena-Duran AV, Monsalve V, Cerda-Olmedo G. Lack of evidence for retroviral infections formerly related to chronic fatigue in Spanish fibromyalgia patients. Virol J. 2013;10:332.

23. Strahler J, Fischer S, Nater UM, Ehlert U, Gaab J. Norepinephrine and epinephrine responses to physiological and pharmacological stimulation in chronic fatigue syndrome. Biol Psychol. 2013;94:160-6.

24. Hall KT, Kossowsky J, Oberlander TF, KaptchukTJ, Saul JP, Wyller VB, Fagermoen E, Sulheim D, Gjerstad J, Winger A, Mukamal KJ. Genetic variation in catechol-O-methyltransferase modifies effects of clonidine treatment in chronic fatigue syndrome. Pharmacogenomics J. 2016;16:454-60.

25. Wyller VB, Vitelli V, Sulheim D, Fagermoen E, Winger A, Godang K, Bollerslev J. Altered neuroendocrine control and association to clinical symptoms in adolescent chronic fatigue syndrome: a cross-sectional study. J Transl Med. 2016;14:121.

26. He J, Hollingsworth KG, Newton JL, Blamire AM. Cerebral vascular control is associated with skeletal muscle pH in chronic fatigue syndrome patients both at rest and during dynamic stimulation. Neuroimage Clin. 2013:2:168-73

27. Vangeel E, Van Den Eede F, Hompes T, Izzi B, Del Favero J, Moorkens G, Lambrechts D, Freson K, Claes S. Chronic fatigue syndrome and DNA hypomethylation of the glucocorticoid receptor gene promoter $1 \mathrm{~F}$ region: associations with HPA axis hypofunction and childhood trauma. Psychosom Med. 2015;77:853-62.

28. Fenouillet E, Vigouroux A, Steinberg JG, Chagvardieff A, Retornaz F, Guieu $R$, Jammes Y. Association of biomarkers with health-related quality of life and history of stressors in myalgic encephalomyelitis/chronic fatigue syndrome patients. J Transl Med. 2016;14:251.

29. Jammes Y, Steinberg JG, DelliauX S. Chronic fatigue syndrome: acute infection and history of physical activity affect resting levels and response to exercise of plasma oxidant/antioxidant status and heat shock proteins. J Intern Med. 2012:272:74-84.

30. Lengert N, Drossel B. In silico analysis of exercise intolerance in myalgic encephalomyelitis/chronic fatigue syndrome. Biophys Chem. 2015;202:21-31.

31. Caccamo D, Cesareo E, Mariani S, Raskovic D, lentile R, Curro M, Korkina L, De Luca C. Xenobiotic sensor- and metabolism-related gene variants in environmental sensitivity-related illnesses: a survey on the Italian population. Oxid Med Cell Longev. 2013;2013:831969.

32. Ciregia F, Giusti L, Da Valle Y, Donadio E, Consensi A, Giacomelli C, Sernissi F, Scarpellini P, Maggi F, Lucacchini A, Bazzichi L. A multidisciplinary approach to study a couple of monozygotic twins discordant for the chronic fatigue syndrome: a focus on potential salivary biomarkers. J Transl Med. 2013;1 1:243.

33. Maltese PE, Venturini L, Poplavskaya E, Bertelli M, Cecchin S, Granato M, Nikulina SY, Salmina A, Aksyutina N, Capelli E, et al. Genetic evaluation of AMPD1, CPT2, and PGYM metabolic enzymes in patients with chronic fatigue syndrome. Genet Mol Res. 2016;15(3):1-10. doi:10.4238/ gmr.15038717.

34. Ciregia F, Kollipara L, Giusti L, Zahedi RP, Giacomelli C, Mazzoni MR, Giannaccini G, Scarpellini P, Urbani A, Sickmann A, et al. Bottom-up proteomics suggests an association between differential expression of mitochondrial proteins and chronic fatigue syndrome. Transl Psychiatry. 2016:6:e904.

35. Nijhof SL, Rutten JM, Uiterwaal CS, Bleijenberg G, Kimpen JL, Putte EM. The role of hypocortisolism in chronic fatigue syndrome. Psychoneuroendocrinology. 2014;42:199-206.

36. Vermeulen RC. Vermeulen van Eck IW: decreased oxygen extraction during cardiopulmonary exercise test in patients with chronic fatigue syndrome. J Transl Med. 2014;12:20.

37. Fluge O, Mella O, Bruland O, Risa K, Dyrstad SE, Alme K, Rekeland IG, Sapkota D, Rosland GV, Fossa A, et al. Metabolic profiling indicates impaired 
pyruvate dehydrogenase function in myalgic encephalopathy/chronic fatigue syndrome. JCl insight. 2016;1:e89376.

38. Tomic S, Brkic S, Maric D, Mikic AN. Lipid and protein oxidation in female patients with chronic fatigue syndrome. Arch Med Sci. 2012;8:886-91.

39. Castro-Marrero J, Cordero MD, Saez-Francas N, Jimenez-Gutierrez C, Aguilar-Montilla FJ, Aliste L, Alegre-Martin J. Could mitochondrial dysfunction be a differentiating marker between chronic fatigue syndrome and fibromyalgia? Antioxid Redox Signal. 2013;19:1855-60.

40. Boles RG, Zaki EA, Kerr JR, Das K, Biswas S, Gardner A. Increased prevalence of two mitochondrial DNA polymorphisms in functional disease: are we describing different parts of an energy-depleted elephant? Mitochondrion. 2015;23:1-6.

41. Brown AE, Jones DE, Walker M, Newton JL. Abnormalities of AMPK activation and glucose uptake in cultured skeletal muscle cells from individuals with chronic fatigue syndrome. PLoS ONE. 2015;10:e0122982.

42. Ghosh D, Poisson LM. "Omics" data and levels of evidence for biomarker discovery. Genomics. 2009;93:13-6.

43. Fluge O, Risa K, Lunde S, Alme K, Rekeland IG, Sapkota D, Kristoffersen EK, Sorland K, Bruland O, Dahl O, Mella O. B-lymphocyte depletion in myalgic encephalopathy/chronic fatigue syndrome. An open-label phase ii study with rituximab maintenance treatment. PLoS ONE. 2015;10:e0129898.
44. Naviaux RK, Naviaux JC, Li K, Bright AT, Alaynick WA, Wang L, Baxter A, Nathan N, Anderson W, Gordon E. Metabolic features of chronic fatigue syndrome. Proc Natl Acad Sci USA. 2016;113:E5472-80.

45. Yamano E, Sugimoto M, Hirayama A, Kume S, Yamato M, Jin G, Tajima S, Goda N, Iwai K, Fukuda S, et al. Index markers of chronic fatigue syndrome with dysfunction of TCA and urea cycles. Sci Rep. 2016;6:34990.

46. Germain A, Ruppert D, Levine SM, Hanson MR. Metabolic profiling of a myalgic encephalomyelitis/chronic fatigue syndrome discovery cohort reveals disturbances in fatty acid and lipid metabolism. Mol BioSyst. 2017;13:371-9

47. Nacul L, Lacerda EM, Kingdon CC, Curran H, Bowman EW. How have selection bias and disease misclassification undermined the validity of myalgic encephalomyelitis/chronic fatigue syndrome studies? J Health Psychol. 2017. doi:10.1177/1359105317695803.

48. US Institute or Health. Estimates of funding for various research condition and disease categories. 2014. https://report.nih.gov/categorical_spending.aspx. Accessed 20 Apr 2017.

49. Fukuda K, Straus SE, Hickie I, Sharpe MC, Dobbins JG, Komaroff A. The chronic fatigue syndrome: a comprehensive approach to its definition and study. International chronic fatigue syndrome study group. Ann Intern Med. 1994;121:953-9.

\section{Submit your next manuscript to BioMed Central and we will help you at every step:}

- We accept pre-submission inquiries

- Our selector tool helps you to find the most relevant journal

- We provide round the clock customer support

- Convenient online submission

- Thorough peer review

- Inclusion in PubMed and all major indexing services

- Maximum visibility for your research

Submit your manuscript at www.biomedcentral.com/submit 